\title{
The University Ideological and Political Teaching Reform under the Concept of "Internet Plus"
}

\author{
Shiqiang Shen \\ Yunnan College of Business Management, Kunming City, Yunnan Province, 650106, China
}

Keywords: "Internet Plus", University, Ideological and political education, Reform

\begin{abstract}
In order to adapt to the challenge of the "Internet Plus" storm and improve the effectiveness and pertinence of the ideological and political theory course, the teaching mode must change and keep pace with the times. Under the background of "Internet Plus", college students 'life style, mode of study, mode of entertainment, communication mode and mode of thinking are influenced implicitly. This paper studied the way of obtaining college students' information under this environment. Based on the empirical research, the new situation of ideological and political education in college students is studied and analyzed. It is of great practical and theoretical significance to further strengthen and improve the ideological and political education of college students and to construct the working discourse system suitable for the needs of the times and the needs of youth development. Based on the author 's study and practical experience, this paper first analyzed the inevitability of the reform of teaching mode in the context of "Internet Plus", then put forward the ways of college students 'ideological and political teaching reform under the background of "Internet Plus".
\end{abstract}

\section{Introduction}

Since the reform and opening up, the teaching of ideological and political class in colleges and universities has made great breakthrough in content and method, and achieved remarkable results. However, we must clearly see that with the arrival of Internet Plus era, the university teaching of ideological and political education will face new opportunities and challenges, and the traditional education barriers are to be broken; moreover, the depth of integration of internet and education will bring about comprehensive change in educational technology, teaching means, etc, so that to bring comprehensive subversion on the concept of education and talents training. At present, in some universities' ideological and political teaching, there are such problems as single teaching method, backward teaching methods, boring and depressed classroom. As a result, students' learning enthusiasm and initiative are not high and teaching quality is poor. Therefore, only by deepening the reform of ideological and political teaching and exploring new teaching methods, can we constantly enhance the effectiveness and pertinence of the teaching of ideological and political courses.

\section{The Inevitability of Teaching Mode Reform under the Background of "Internet Plus"}

Signed and approved by Premier Li Keqiang on July 2015, the State Council issued the "guiding opinion on actively promoting the Internet Plus" a few days ago, which uses modern information and communication technology and Internet platform. It will combine the Internet with the traditional industry to create a new form of development. In the field of education, the results of the "Internet Plus" will lead that all "teaching" and "learning" activities in the future revolve around the Internet. The ideological and political theory course, as a required course for the students of various major colleges and universities, is the main position to train students to set up a correct outlook on life, world outlook and values. As an important field of ideological work, ideological and political theory courses in colleges and universities must be combined with Internet technology and actively participate in the technological change in the field of education. It also can make the development of Internet and information technology better serve the spread and influence of ideological and political theory and Marxism among young college students, and promote the network development 
of value education of college students.

\section{The Path of Ideological and Political Teaching Reform of College Students under the Background of "Internet Plus"}

\subsection{Promoting the Transformation of Work Innovation with the Effect of New Media Construction}

The social transformation of modernization is not only the transformation of social economic operation mode, but also the transformation of social psychology, value system and behavior mode of a country or nation. The society and the young generation are in the evolution of the new and old social value system. During the forming period of the new values, the dismemberment of the unity of the social value system by postmodernism undoubtedly intensifies the confusion of the social value standards, and to a certain extent affects the establishment of the core values of the younger generation. Therefore, to innovate the discourse system of network ideological and political education, we should guide students in the way of students' thinking and deepen the guidance of core values with the construction of new media. It should be helpful to strengthen the pertinence of mainstream ideological education and the effectiveness of the implementation of network ideological and political education discourse. First, we should study and implement the spirit of the 18th CPC Central Committee, the Fifth Plenary session as an opportunity to seize the opportunity of Anniversary of the War of Resistance against Japan and the anniversary of the founding and other important time nodes so that to conduct theme Party Day and Campus Culture Exhibition as popular ways accepted by students. The second is to expand the influence of the network ideological and political education work with the construction of new media. The ideological and political education of college students must lead and serve the young people, and win the recognition of the work by setting up the word of mouth. The third is to use new media work to improve working methods. We should effectively improve the working mechanism, strengthen team construction and enhance the effectiveness of the work. Many colleges and universities established a network of volunteers and advocates team of network civilization. We should give full play to their subjective initiative and make them become the main force of carrying forward positive energy on the network so as to promote the ideological and political education of college students.

\subsection{Strengthening the Transmission of the Carrier of Ideological Activities on the Internet}

The top-down network regulation is the embodiment of the overall characteristics of network governance, but the technological convenience brought by the Internet makes citizens' participation in politics and social mobilization enter the fast lane and obtain more powerful social power. Any statements made by the online authentication community are easily viewed 5,000 times or retweeted 500 times, and college students' views and ideas on things are easily influenced by these so-called "opinion leaders." In the face of the situation of information explosion, we should consolidate and strengthen the mainstream ideology and public opinion, and strengthen the positive propaganda. The school can publicize the correct new media usage pattern through regular lectures, curriculum guides, community activities, and correctly screen the information. In school public places, especially where college students are more frequent and concentrated, such as canteen, teaching area, dormitory and gymnasium, with the help of LED screen, electronic scroll bar and other electronic devices, we want to cycle the correct use of new media, which can play an effective role in publicity. After that, final results will be reflected in the daily behavior, so that to enhance the ability of influence under the authenticity of the information. At the same time, schools should also publicize and utilize the characteristics of the popularity of new media, give full play to the platform agglomeration effect of new media, and disseminate important notifications of campus news in a short time by paying attention to and forwarding, so as to produce good communication effects. 


\subsection{Keep Abreast of the Latest Technological and Social Trends}

In 2011, Jeremy Rifkin, chairman of the American Economic Trends Foundation, put forward the concept of the third Industrial Revolution in his book the third Industrial Revolution. He believes that the revolution of the combination of renewable energy and Internet technology will change the world. In the book Zero Marginal Cost Society, he also predicted that future societies would pay more attention to collaboration and sharing. Over the past two years, Internet thinking will spread further. The author believes that several aspects are worth studying: we must face up to the new relationship: The core of Internet thinking is to reduce the intermediate links, eliminate information asymmetry with more efficient and more flat information. Our teacher-student relationship, departmental organization and student relationship are all changing. We have to use big data well: The pain point thinking, explosive point thinking, flow thinking and integrated thinking in the 12 core thinking of the Internet need to be realized with the help of big data and the Internet of things, which was raised by Zhong Dianzhou's book Internet thinking. Because big data can actually drive us more focused on data-speaking rather work than empirical work. The diversification of students' needs and the variability also force students' work to use the big data technology to grasp the students' ideological trend more accurately, the areas they concern and the excitement of their lives. New youth must be guided hand in hand: The college students of "the post 90s" and "The post 95s" are born and live on the internet and are regarded as the "indigenous people" of the internet. They are born with the new gene of the internet and completely different from the "post 70s" and "post 80s". Therefore, it is necessary to strengthen the learning of the Internet, learn the characteristics of the Internet, and learn the law of the Internet. Taking East China University as an example, the Communist Party Committee of the Communist Party of China (CPC) has established a new media development center, and the Publicity Department of the Party Committee has "Qingyu" network cultural studio. These three platforms complement each other and develop in a coordinated manner, and work together to promote the ideological and political education of the school network.

\subsection{Enhancing the Self-adjustment of Students' Life under the "Net"}

The emergence of mobile phones and tablet devices has formed a large group of "Phubber"; young students account for many of them, whether walking, eating, or during class. They can't help looking down at new media such as their phones and tablets. Some students are more addicted to the Internet. Therefore, school teachers and counselors should encourage and guide college students to moderately use new media tools, and start with the rejection of "Phubber" and start from the reading return of traditional newspapers and magazines, and enhance the guidance of college students' online self-adjustment. In addition, colleges and universities focus on the school mainstream website and virtual network communication platform and other network media platforms, but also need to strengthen offline physical platform construction, such as campus broadcasting, psychological counseling room so as to achieve a wide range of online and offline coverage, diverse channels of campus propaganda. This is the key direction of ideological and political education for college students in the new period.

\section{Conclusions}

To some extent, the Internet has overturned our traditional mode of ideological and political education-young students will no longer accept all the knowledge or ideas we impart. And we need to express our ideas in a popular way, such as micro video, online lectures, and so on. This is the organic combination of Ideological and political education and the Internet, as well as an important part of the "Internet Plus University". By changing the concept of work and improving the working methods, we have reason to believe that the ideological and political education of college students on the network will be more recognized and accepted by the students. As ideological and political educators in colleges and univerasities, we should be full of confidence, despite the challenges that come with "Internet Plus". This is the basis for our ideological and political educators and the precondition to do a good job. 


\section{References}

[1] Ouyang Haifeng. An Analysis of College Students ' Ideological and Political Education under the New Media Environment [J]. China Hi-tech Zone, 2017, (18): 85.

[2] Ma Yueming, Wang Aijin. A New Approach to the Teaching of Ideological and Political Theory under the Environment of "Internet Plus" [J]. The Journal of Higher Education is 14: 94-95.

[3] Tang Zhaoyun, Jiang Xiaoming, Kuang Limin. Innovation and Application of Teaching Method of Ideological and Political Course Based on Internet Cloud Platform Space [J]. Higher Education in China, 2017, (11):56-58.

[4] Wang Xiaoxiao, Nie Fenghua, Wu Xia. The Construction and Practice in the Course of Ideological and Political Theory of Tsinghua University [J]. Modern Education Technology, 2016, (08): 83-88.

[5] Peng Li. On the Reform of Ideological and Political Theory Course under the "Internet Plus" [J]. Journal of Southwest University of Science and Technology (Philosophy and Social Science Edition), 2016, (02): 93-96+100.

[6] Deng Wei. Promoting the Reform and Innovation of Teaching Mode to Improve the Pertinence and Effectiveness of the Ideological and Political Courses [J]. China's Higher Education: 21: 18-20.

[7] Liu Hui. A study on the Reform of the Teaching Mode of Ideological and Political Education under the Background of "Internet Plus" [J]. Education in Asia and the Pacific, 2015, (27):74. 